\title{
Enzyme-immobilized hydrogels to create hypoxia for in vitro cancer cell culture
}

Camron S. Dawes, ${ }^{1}$ Heiko Konig, ${ }^{2,3}$ and Chien-Chi Lin ${ }^{1,3,{ }^{*}}$

${ }^{1}$ Department of Biomedical Engineering, Indiana University-Purdue University Indianapolis, Indianapolis, IN, 46202, USA

2 Department of Medicine, Division of Hematology/Oncology, Indiana University School of Medicine, Indianapolis, IN, 46202, USA

${ }^{3}$ Indiana University Melvin \& Bren Simon Cancer Center, Indianapolis, IN, 46202, USA

*To whom correspondence should be made:

Prof. Chien-Chi Lin

Associate Professor of Biomedical Engineering

Indiana University-Purdue University Indianapolis

723 W. Michigan St. SL220K

Indianapolis, IN 46202

Phone: (317)274-0760

Email: lincc@iupui.edu 


\section{Abstract}

Hypoxia is a critical condition governing many aspects of cellular fate processes. The most common practice in hypoxic cell culture is to maintain cells in an incubator with controlled gas inlet (i.e., hypoxic chamber). Here, we describe the design and characterization of enzymeimmobilized hydrogels to create solution hypoxia under ambient conditions for in vitro cancer cell culture. Specifically, glucose oxidase (GOX) was acrylated and co-polymerized with poly(ethylene glycol)-diacrylate (PEGDA) through photopolymerization to form GOXimmobilized PEG-based hydrogels. We first evaluated the effect of soluble GOX on inducing solution hypoxia $\left(\mathrm{O}_{2}<5 \%\right)$ and found that both unmodified and acrylated GOX could sustain hypoxia for at least 24 hours even under ambient air condition with constant oxygen diffusion from the air-liquid interface. However, soluble GOX gradually lost its ability to sustain hypoxia after 24 hours due to the loss of enzyme activity over time. On the other hand, GOXimmobilized hydrogels were able to create hypoxia within the hydrogel for at least 120 hours, potentially due to enhanced protein stabilization by enzyme 'PEGylation' and immobilization. As a proof-of-concept, this GOX-immobilized hydrogel system was used to create hypoxia for in vitro culture of Molm14 (acute myeloid leukemia (AML) cell line) and Huh7 (hepatocellular carcinoma (HCC) cell line). Cells cultured in the presence of GOX-immobilized hydrogels remained viable for at least 24 hours. The expression of hypoxia associated genes, including carbonic anhydrase 9 (CA9) and lysyl oxidase (LOX), were significantly upregulated in cells cultured with GOX-immobilized hydrogels. These results have demonstrated the potential of using enzyme-immobilized hydrogels to create hypoxic environment for in vitro cancer cell culture.

Keywords: Hypoxia; cancer; hydrogel; enzyme immobilization; glucose oxidase. 


\section{Introduction}

Hypoxia, the lack of adequate oxygen $\left(\mathrm{O}_{2}\right)$ supply in cells and tissues, is a physiological condition of many healthy and diseased tissues in the body. For example, $\mathrm{O}_{2}$ concentration is around $20 \%$ in the lungs; $\sim 13 \%$ in the alveoli; $\sim 5 \%$ in the circulation system and the bone marrow; and below 5\% in multicellular tissues (De Miguel et al., 2015; Simon and Keith, 2008). Hypoxia is implicated in both normal physiological events and pathological conditions, including ischemia, tumors, and inflamed tissues. As such, $\mathrm{O}_{2}$ concentration should be considered as a critical experimental condition when performing in vitro cell studies (Hockel and Vaupel, 2001; Liu and Simon, 2004; Semenza, 2000; Simon and Keith, 2008). Hypoxia stabilizes the expression of hypoxia inducible factors (HIFs) (Semenza, 2000), which are heterodimeric transcription factors that regulate many downstream genes and cell fate processes (Liu and Simon, 2004; Semenza, 2000), including proliferation, metabolism, apoptosis, stress response, angiogenesis, and migration. Hypoxia is also a key factor regulating tumor growth and drug resistance (De Miguel et al., 2015; Giaccia et al., 2003; Hockel and Vaupel, 2001; Liu and Simon, 2004).

The gold standard to induce hypoxia $\left(\left[\mathrm{O}_{2}\right]<5 \%\right)$ for in vitro cell culture is through using a cell culture chamber with controlled gas supplies (i.e., hypoxic chamber). However, the time needed to reach equilibrium of $\mathrm{O}_{2}$ partial pressure between the chamber atmosphere and the culture medium could take several hours (Allen et al., 2001). Another challenge of using a hypoxic chamber is that $\mathrm{O}_{2}$ diffusion from the air to the cell culture media occurs rapidly once the culture plates are removed from the hypoxic chamber. Unfortunately, studies have shown that even brief exposure of some cells to ambient air would cause drastic changes in certain hypoxia-related gene expression (Broxmeyer et al., 2015). For this reason, a glovebox is required if one wishes to maintain hypoxia throughout the experiment. The high front-end cost

and dedicated space required for a hypoxic chamber system also limit its implementation to selected laboratories. In addition, it is challenging to perform real-time imaging or other 
instrument-based live cell assays under hypoxia even with the use of a glovebox. Furthermore, one hypoxic chamber system can only provide one fixed $\mathrm{O}_{2}$ tension for one experiment, which significantly retards the progress of scientific discovery related to varied $\mathrm{O}_{2}$ tensions (e.g., hypoxia gradient, multiplex hypoxic drug testing, etc.).

Another method to induce hypoxia for cell culture is through introducing pre-equilibrated media with lower $\mathrm{O}_{2}$ tension into the cell culture vessels, such as bioreactors or microfluidic devices. Bioreactors are the standard operation for scale-up production of cells or biological products but not ideal for mechanistic studies of hypoxia-induced cellular response. On the other hand, a microfluidic culture system permits real-time imaging of hypoxic cell culture and allows creation of complex hypoxia patterns within the confined microenvironment. For example, Peng et al. used chemical scavengers to reduce aqueous $\mathrm{O}_{2}$ content within a patterned array of cells in wells of a microfluidic device with geometry matching that of a 96-well plate (Peng et al., 2013). This method is beneficial in that multiple $\mathrm{O}_{2}$ profiles can be developed rapidly through pre-equilibrated media in different wells of a single device. However, setting up microfluidic cell culture requires special instruments and project-specific microfluidic design. The applicability of such system in higher or enhanced-throughput analysis is also limited (e.g., drug screening and testing under various hypoxic conditions). It is also not an easy task to integrate microfluidic system with three-dimensional (3D) cell culture.

Hypoxic response in the cells can also be simulated using chemicals that upregulate or stabilize the expression of HIF1 $\alpha$. Cobalt chloride $\left(\mathrm{CoCl}_{2}\right)$ or desferrioxamine are two examples of such chemicals (An et al., 1998). Although this is a relatively simple strategy to mimic hypoxic response in the cells, the use of chemical only regulates cellular and molecular responses directly downstream of HIF. Furthermore, these chemicals could affect cell survival, metabolism, and morphology differently compared to real $\mathrm{O}_{2}$ deprivation (Han et al., 2006).

Recently, $\mathrm{O}_{2}$-consuming enzymatic reactions are being developed as an alternative route to the aforementioned methods. The most notable example is the use of glucose oxidase 
(GOX) and catalase (CAT) (Gibson et al., 1964; Kirkman and Gaetani, 2007). GOX oxidizes $\beta$ D-glucose while consuming $\mathrm{O}_{2}$ to produce gluconic acid and hydrogen peroxide $\left(\mathrm{H}_{2} \mathrm{O}_{2}\right)$. CAT is commonly added to reduce the cytotoxic $\mathrm{H}_{2} \mathrm{O}_{2}$ to one mole of water and a half mole of $\mathrm{O}_{2}$ (Figure 1A). This system has been used to induce hypoxia in solutions and in microfluidic devices (Askoxylakis et al., 2011; Baumann et al., 2008; Huang et al., 2013; Li et al., 2016; Millonig et al., 2009; Mueller et al., 2009; Rajan et al., 2013; Sobotta et al., 2013; Zitta et al., 2012). The use of GOX/CAT is beneficial in that the system provides a rapid onset of hypoxia (usually within a few minutes) (Askoxylakis et al., 2011; Baumann et al., 2008; Huang et al., 2013; Li et al., 2016; Millonig et al., 2009; Mueller et al., 2009; Rajan et al., 2013; Sobotta et al., 2013; Zitta et al., 2012). One drawback to any GOX system, however, is the production of hydrogen peroxide, a reactive oxygen species (ROS) (Fruehauf and Meyskens, 2007) whose accumulation would not only cause undesired cellular response but also inactivate both GOX and CAT (Hielscher and Gerecht, 2015; Pal et al., 2000; Trachootham et al., 2009; Tse and Gough, 1987). Thus far, the applications of GOX/CAT system have been focused on glucose sensing and $\mathrm{pH}$-induced responses (Wu et al., 2011). For example, Choi et al. prepared GOXimmobilized poly(ethylene glycol) (PEG) hydrogels and studied the effect of gel compositions on immobilized enzyme activity. Although the production of $\mathrm{H}_{2} \mathrm{O}_{2}$ was quantified to evaluate kinetics of the immobilized enzyme kinetics, $\mathrm{O}_{2}$ contents were not monitored (Choi et al., 2008). Some recent work has started to explore the ability of GOX/CAT reactions to induce hypoxia for in vitro cell culture (Askoxylakis et al., 2011; Baumann et al., 2008; Huang et al., 2013; Li et al., 2016; Millonig et al., 2009; Mueller et al., 2009; Rajan et al., 2013; Sobotta et al., 2013). The GOX/CAT system has also been adapted to 3D printed inserts (Li et al., 2016) where GOX and CAT were coated on printed disks and the degrees of solution hypoxia were controlled by the distance between the enzyme-immobilized disks and the solution in the culture plate. In that design, hypoxia conditions (between 0 and $\sim 12 \% \mathrm{O}_{2}$ ) were maintained for up to 5 hours and the system was used to induce hypoxic response in peritoneal macrophages. 
Other enzymes (e.g., laccase) have also been used to create hypoxia (Blatchley et al., 2015; Park et al., 2014; Park and Gerecht, 2014). In the laccase system, a fixed amount of substrate (i.e., ferulic acid, FA) was immobilized to a polymer backbone. The FA-immobilized polymer was then crosslinked by laccase-mediated enzymatic reaction, which also consumes $\mathrm{O}_{2}$. Recently, Lewis et al. extended the timespan of laccase-induced hypoxia by limiting the diffusion of $\mathrm{O}_{2}$ into the FA-crosslinked hydrogel. Together with the enzymatic $\mathrm{O}_{2}$ depletion, the system was successfully used to study the impact of hypoxia on sarcoma cell invasion and migration (Lewis et al., 2016).

Here, we present an immobilized enzyme strategy for inducing hypoxia within and surrounding the PEG-based hydrogel for in vitro cancer cell culture. Immobilization of oxygenconsuming GOX within covalently crosslinked hydrogels provide an easy method to control solution oxygen tension without using external devices. Furthermore, GOX-immobilized hydrogels can be readily added to or removed from cell culture without disturbing cells. The crosslinked PEG hydrogel network also provides opportunities for immobilizing multiple proteins/enzymes or other functional molecules for other biomedical applications. In this contribution, we systematically studied the ability of GOX, PEG-acrylate modified GOX (i.e., GOX $_{P E G A}$ ), and GOX-immobilized hydrogels to induce solution hypoxia. Furthermore, we utilized GOX-immobilized hydrogels to induce hypoxia for in vitro culture of anchorage-independent acute myeloid leukemia cells Molm14 and anchorage-dependent hepatocellular carcinoma cells Huh7. We evaluated the effects of GOX-immobilized hydrogels on cancer cell fate, including viability, proliferation, and hypoxia-associated gene expression.

\section{Materials \& methods}

Linear PEG (Mn = 2 kDa) was purchased from Sigma-Aldrich. Glucose oxidase (0243$500 \mathrm{KU})$ and catalase (LS001847) were purchased from Amresco and Worthington Biochemical, respectfully. Acrylate-PEG-succinimidyl valerate (Acryl-PEG-SVA, MW 3,400 Da) was obtained 
from Laysan Bio Inc. Zeba Spin Desalting Columns (7K MWCO), 2,4,6-trinitrobenzene sulfonic acid (TNBSA), and $\beta$-D-glucose were purchased from Thermo Scientific. Penicillin-streptomycin, antibiotic-antimycotics, fetal bovine serum (FBS), Roswell Park Memorial Institute media (RPMI), and Dulbecco's modified Eagle's medium (DMEM) were acquired from Life Technologies. HEPES and Dulbecco's phosphate-buffered saline (DPBS) were purchased from Lonza. Membrane culture plate inserts (PIXP-012-50) were purchased from EMD Millipore. Tryphan blue and AlamarBlue® reagents were purchased from Mediatech and Fisher Scientific, respectfully.

\subsection{Macromer synthesis and characterization}

PEG-diacrylate (PEGDA) was synthesized according to an established protocol (Hao and Lin, 2014) and characterized with ${ }^{1} \mathrm{H}-\mathrm{NMR}$ (Bruker 500). The degree of PEGDA functionalization was around 89\% (Figure S1). Photoinitiator lithium aryl phosphonate (LAP) was synthesized as described elsewhere (Fairbanks et al., 2009).

To facilitate enzyme immobilization within hydrogels, glucose oxidase was acrylated using Acryl-PEG-SVA (Choi et al., 2008). Briefly, the enzyme was first dissolved at $20 \mathrm{mg} / \mathrm{mL}$ in PBS supplemented with $2 \mathrm{mM}$ EDTA (pH 8.5) and $50 \mathrm{mM}$ sodium carbonate. Acryl-PEG-SVA was added at 200x molar excess to enzyme concentration and the reaction was allowed to proceed at room temperature for 2 hours with stirring. During the reaction, primary amines on the surface of the enzyme reacted with SVA groups to afford PEG-acrylate (PEGA)-modified GOX (GOX columns (Zeba Spin Desalting column). Un-modified GOX at the same concentration was also passed through the columns and used as controls to account for any loss/entrapment of enzyme within the columns. Following synthesis, both GOX and GOX TNBSA assay to determine the degree of PEGA functionalization. For each assay, enzyme samples were diluted to $30-35 \mu \mathrm{g} / \mathrm{mL}$. A series of lysine hydrochloride solutions $(0-10 \mu \mathrm{g} / \mathrm{mL}$, 
$200 \mu \mathrm{L} /$ well) were used as standards. $100 \mu \mathrm{L}$ of $0.01 \%$ TNBSA reagent was added into wells of a 96-well plate, which was sealed and incubated at $37^{\circ} \mathrm{C}$ for 2 hours, followed by cooling for 5 minutes. Absorbance at $335 \mathrm{~nm}$ was measured using a microplate reader (SynergyHT BioTek). The degree of PEGA functionalization on GOX was determined as the concentration of remaining amine groups on GOX $\mathrm{PEGA}_{\mathrm{A}}$ over that of the un-modified GOX.

\subsection{Characterization of enzymatic activity of GOX $X_{P E G A}$}

To examine the enzyme activity, $\mathrm{O}_{2}$ consumption in the presence of the enzyme and glucose was quantified. The changes in $\mathrm{O}_{2}$ content over time in the presence of GOX or $\operatorname{GOX}_{\mathrm{PEGA}}\left(\mathrm{V}_{\mathrm{O}}=\Delta\left[\mathrm{O}_{2}\right] / \Delta \mathrm{Time}\right)$ was defined as the reaction velocity. Enzyme was dissolved PBS $(\mathrm{pH} 7.4)$ at $0.13 \mu \mathrm{M}$ in a $2 \mathrm{~mL}$ microtube with constant stirring at $25^{\circ} \mathrm{C}$. The oxygen consumption reactions were carried out under ambient air with constant oxygen diffusion from the air to mimic actual cell culture condition. Stock $\beta$-D-glucose solution was injected at the start of every measurement to give starting concentrations of 0.30 to $25 \mathrm{mM}[\mathrm{S}]$. Dissolved $\mathrm{O}_{2}$ concentration was monitored for 3 minutes using an $\mathrm{O}_{2}$ probe and meter (Microx4, PreSens). $\mathrm{O}_{2}$ contents were plotted as a function of time and the initial linear portion of the curve was used for $V_{0}$ calculation (change in substrate concentration over time). Non-linear regression analysis and curve fitting was applied to paired $V_{0}$ and $[S]_{1}$ using the equation $V_{o}=V_{\max } \cdot[S] /(K m+[S])$. In the equation, $V_{\max }$ is the theoretical maximum enzyme reaction velocity and $K_{m}$ is the MichaelisMenten constant, the equilibrium dissociation constant (i.e., affinity) for the enzyme and the substrate.

\subsection{Synthesis and characterization of enzyme-immobilized hydrogels}

All macromer solutions were sterilized by passing through $0.22 \mu \mathrm{m}$ syringe filters. PEGDA hydrogels (15 wt\%) were polymerized aseptically through radical mediated photopolymerization in the absence or presence of GOX PEGA $_{\text {monomer }}(6 \mathrm{mg} / \mathrm{mL})$, and LAP (1 $\mathrm{mM}$ ) as the photoinitiator. $60 \mu \mathrm{L}$ gels were injected between two glass slides separated by 
Teflon spacers $(2 \mathrm{~mm})$ and gelation was initiated with a UV lamp $\left(365 \mathrm{~nm}, 5 \mathrm{~mW} / \mathrm{cm}^{2}, 2 \mathrm{~min}\right.$ exposure). Following photopolymerization, hydrogels ( $3.1 \mathrm{~mm}$ dia. $\times 2 \mathrm{~mm}$ thickness) were incubated in DPBS for 24 hours at $37^{\circ} \mathrm{C}$.

$\mathrm{O}_{2}$ concentration in solution was measured with a dipping-type $\mathrm{O}_{2}$ sensor (Microx4, PreSens). For solution based measurements, the probe was extended to $\sim 2 \mathrm{~mm}$ above the bottom of the 24 well plate or $1 \mathrm{~mm}$ above the gel $(\sim 2 \mathrm{~mm}$ from the liquid-air interface). To measure the $\mathrm{H}_{2} \mathrm{O}_{2}$ produced during the reactions, $10 \mu \mathrm{L}$ aliquots of the solutions were collected and quantified with a Quantichrom Peroxide Assay Kit following the manufacturer's protocol (BioAssay Systems).

\subsection{Cell culture and viability assays}

A suspension cell type, human acute myeloid leukemia (AML) cells Molm14, was purchased from Leibniz Institute, German Collection of Microorganisms and Cell Cultures. Cells were maintained in RPMI media supplemented with $10 \%$ fetal bovine serum (FBS) and $1 \%$ penicillin-streptomycin $25 \mathrm{mM}$ HEPES, and $25 \mathrm{mM} \beta$-D-Glucose. 400,000 cells $/ \mathrm{mL}$ of Molm14 cells were seeded per well in non-treated 24 well plates. GOXPEGA gels (15 wt\% PEGDA, 6 $\mathrm{mg} / \mathrm{mL}$ GOX ${ }_{P E G A}, 60 \mu \mathrm{L}$ per gel) were added to half of the wells (one gel per well) containing $0.54 \mathrm{mg} / \mathrm{mL}$ catalase. Remaining wells were placed with gels without immobilized enzyme. In vitro $\mathrm{O}_{2}$ concentration was measured $\sim 1 \mathrm{~mm}$ above the hydrogel with a dipping-type $\mathrm{O}_{2}$ sensor (PreSens). Adherent cell type human hepatocellular carcinoma cells (Huh7) were grown in high glucose DMEM supplemented with 10\% FBS, 1\% antibiotic antimycotics, and 25 mM HEPES. Cells were seeded on treated 24 well plates with $1 \mathrm{~mL}$ per well of cell suspension $(60,000$ cells $/ \mathrm{mL}$ ) and allowed to grow/spread for 48 hours prior to the onset of the experiments, at which time (labeled as 0 hours) culture media was refreshed in all wells. At the onset of the experiment, membrane inserts containing GOX $\mathrm{PEGA}_{\mathrm{A}}$ gels were placed in the wells and the 
medium was supplemented with $0.54 \mathrm{mg} / \mathrm{mL}$ CAT. Half of the wells only had media refreshed and were used as control groups for the experiment (no enzyme added).

Molm14 cell viability and density were characterized by tryphan blue staining and counting with a hemocytometer. AlamarBlue® reagent (10x dilution in media) was used for assaying metabolic activity of Huh7 cells. After a 90 min incubation, $200 \mu \mathrm{L}$ from each well was transferred to a clear 96-well microplate and read for fluorescence (excitation/emission: 560/590 $\mathrm{nm})$.

\subsection{RNA isolation and real time PCR}

RNA isolation was carried out using NucleoSpin RNA II kit (Clontech). Briefly, $600 \mu \mathrm{L}$ of lysis buffer was added to each well containing cells. Cell lysates were snap frozen and stored in $-80^{\circ} \mathrm{C}$ until assay. After thawing the lysates, $600 \mu \mathrm{L}$ of $70 \% \mathrm{RNase}$ free ethanol was added, pipetted vigorously, and then run through NucleoSpin RNA columns. After desalting/purification steps, RNA was eluted with DNase/RNase-free $\mathrm{H}_{2} \mathrm{O}$ and quantified by spectroscopy (NanoDrop 2000, Thermo Scientific). Isolated RNA was stored at $-80^{\circ} \mathrm{C}$.

Complementary DNA was generated from the isolated total RNA by using PrimeScript $\mathrm{RT}$ reagent kit (Clontech, TaKaRa). Gene expression was analyzed by real time quantitative PCR using SYBR Premix Ex Taq II Kit (Clontech, TaKaRa). The kit components, cDNA, and primers were mixed in a PCR plate and analyzed on a 7500 Fast Real-Time PCR machine (Applied Biosystems). Thermocycling parameters were one cycle at $95^{\circ} \mathrm{C}$ for $30 \mathrm{~s}$, followed by $95^{\circ} \mathrm{C}$ for $3 \mathrm{~s}, 60^{\circ} \mathrm{C}$ for $30 \mathrm{~s}$, and repeat for 45 cycles. Gene expression results were analyzed using $2^{-\Delta \Delta C T}$ methodology. For each experimental condition, cycle count was first standardized to ribosomal $18 \mathrm{~S}$ housekeeping gene ( $\triangle \mathrm{CT}$ level) and then normalized with respect to the media control group for that specific time point $(\Delta \Delta C T$ level; media control values were set as onefold). Table S1 lists all primer sequences used for real-time PCR.

\subsection{Statistics}


GraphPad Prism 5 was used for all curve fitting and statistical analyses. Significance comparison between experimental groups was performed using Two-Way ANOVA with Bonferroni post testing. Michaelis-Menten parameters for GOX and GOXPEGA were generated with the non-linear regression suite in GraphPad Prism 5 software. All experiments were conducted a minimum of three times with data presentation as the mean \pm standard error of the mean (SEM). One, two, or three asterisks represent $p<0.05,0.01$, or 0.001 , respectively.

\section{Results}

\subsection{Enzyme-induced hypoxia}

GOX/CAT systems have been used to induce $\mathrm{pH}$ changes in aqueous environment due to the production of gluconic acid (Figure 1A). To gain insights into the capability of this enzymatic system on inducing hypoxia in solution, we quantified the reduction of $\mathrm{O}_{2}$ in aqueous buffers supplemented with different concentrations of GOX in the absence (Figure 1B) or presence (Figure 1C) of CAT. The $\mathrm{O}_{2}$ tensions of the buffers were monitored using an $\mathrm{O}_{2}$ sensor and recorded as a function of time. As expected, higher concentrations of GOX were able to deplete $\mathrm{O}_{2}$ faster. As shown in Figure 1B, $\mathrm{O}_{2}$ tension was reduced within 5 minutes to $\sim 6 \%$ or to $\sim 2.5 \%$ when $2.25 \mu \mathrm{g} / \mathrm{mL}$ or $4.5 \mu \mathrm{g} / \mathrm{mL}$ of GOX was added, respectively. With the inclusion of $9.8 \mu \mathrm{g} / \mathrm{mL}$ of CAT in the solution, the rate of $\mathrm{O}_{2}$ consumption was slowed down to $\sim 9 \%$ and to $3.2 \%$ within 5 minutes (Figure 1C). The decrease in $\mathrm{O}_{2}$ consumption is not surprising as the addition of CAT produces one-half mole of $\mathrm{O}_{2}$ per mole of $\mathrm{H}_{2} \mathrm{O}_{2}$ consumed.

In order to fabricate enzyme-immobilized hydrogels capable of inducing hypoxia, the primary amine groups on GOX were functionalized with 200-fold molar excess of Acryl-PEGSVA (Figure 2A) (Choi et al., 2008). TNBSA assay results showed an average of $93 \pm 1.7 \%$ (Mean \pm SEM, $N=5$ ) of the primary amines on enzyme surface were functionalized with Acryl-

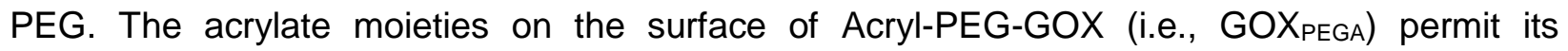
homopolymerization with PEGDA to afford enzyme-immobilized hydrogels. The modification, 
however, could affect the ability of GOXPEGA to consume $\mathrm{O}_{2}$. As shown in Figure 2B, while unmodified GOX caused rapid $\mathrm{O}_{2}$ reduction (from $\sim 20 \%$ to $\sim 3.2 \%$ in 5 minutes) in solution, the ability of GOXPEGA to consume $\mathrm{O}_{2}$ was slightly hindered after Acryl-PEG-SVA modification (from $\sim 20 \%$ to $\sim 5.9 \%$ within 5 minutes). To quantify the impact of polymer modification on its enzyme activity, reaction velocities of GOX and GOX Michaelis-Menten enzyme kinetic parameters were listed in Table 1. Maximum reaction velocity, $\mathrm{V}_{\max }$, was reduced for GOX $\mathrm{PEGA}$ to $0.664 \mathrm{mM} \cdot \mathrm{min}^{-1}$, or approximately $75 \%$ of that for GOX $(0.880$ $\left.\mathrm{mM} \cdot \mathrm{min}^{-1}\right)$. Additionally, $\mathrm{K}_{\mathrm{m}}$, an estimate of the dissociation constant for enzyme and substrate, was also decreased for GOX $\mathrm{PEGA}$ at $1.1173 \mathrm{mM}$ versus $\mathrm{GOX}$ at $4.380 \mathrm{mM}$.

To evaluate the ability of the enzyme system to maintain hypoxia, $\mathrm{O}_{2}$ content measurements were carried out for 72 hours. Figure 3 shows long term solution hypoxia induced by GOX or GOX Between GOX and GOX first 24 hours, $\mathrm{O}_{2}$ was maintained below $5 \%$ but gradually increased to $\sim 13 \%$ by 72 hours (Figure 3A). The addition of CAT did not affect $\mathrm{O}_{2}$ content, which was below $5 \%$ in the first 24 hours for both GOX and GOX 50 and 72 hours, respectively.

\subsection{GOX $X_{P E G A}$-immobilized hydrogels for inducing hypoxia}

GOX method for inducing solution hypoxia. The ability of the immobilized enzyme to reduce $\mathrm{O}_{2}$ in the surrounding solution and within the gel was measured with a needle type optical probe as shown in Figure 4A. With the needle type $\mathrm{O}_{2}$ probe, it was possible to measure $\mathrm{O}_{2}$ content outside (left panel) or inside (right panel) the GOX ${ }_{P E G A}$ immobilized hydrogels (Figure 4B). Control experiments using hydrogels without enzyme immobilization (i.e., (-) GOX PEGA) showed that $\mathrm{O}_{2}$ content remained close to normoxia $\left(17-20 \% \mathrm{O}_{2}\right.$, Figure S2). Furthermore, there was no 
significant difference between $\mathrm{O}_{2}$ content within or outside of the enzyme-free hydrogels. With the use of GOX 'exterior' (i.e., outside of the GOX similar to that with soluble enzyme (Figure 3A). $\mathrm{O}_{2}$ tension was roughly at $\sim 8 \% \mathrm{O}_{2}$ for 48 hours in solution with the GOX $\mathrm{PEGA}_{\mathrm{A}}$ hydrogels. Conversely the $\mathrm{O}_{2}$ tension within the GOX $\mathrm{X}_{\mathrm{PEAA}}$ hydrogel quickly reached and maintained near anoxia $\left(\sim 0 \% \mathrm{O}_{2}\right)$ for 48 hours. The $\mathrm{O}_{2}$ tension at the gel exterior had increased to $\sim 15 \%$ by 120 hours, while that in the gel interior was still below $2 \%$.

\subsection{Combined GOX $\mathrm{XEGA}_{\mathrm{PE}}$-immobilized hydrogels and soluble CAT for inducing hypoxia}

Next, GOX $X_{P E A}$-immobilized hydrogels were placed in buffer solution containing catalase and the solution $\mathrm{O}_{2}$ content was measured (Figure 5A). After placing the GOXPEGA gel, hypoxia was induced and sustained for at least 6 hours. By 24 hours, the $\mathrm{O}_{2}$ content in solution without CAT returned to $\sim 14 \%$, whereas it remained $\sim 6 \%$ in the presence of CAT. By 48 hours, the $\mathrm{O}_{2}$ content returned to $\sim 14 \%$ and $\sim 16 \%$ for solution with or without CAT, respectively. Increasing percent $\mathrm{O}_{2}$ over time would indicate that some degree of enzyme activity was lost. Figure 5B shows that, in the presence of $\mathrm{CAT}, \mathrm{H}_{2} \mathrm{O}_{2}$ concentrations were $2 \mathrm{mM}$ and $5 \mathrm{mM}$ at 24 and 48 hours, respectively. In the absence of CAT, however, $\mathrm{H}_{2} \mathrm{O}_{2}$ concentration increased to $\sim 9 \mathrm{mM}$ at both time points. To ensure that glucose was not exhausted during the GOX reaction, we supplemented the solution with additional D-glucose at later time points. A $50 \mu \mathrm{L}$ shot of $\beta$-Dglucose (at $50 \mathrm{mM}$ ) was added to the solution $(1000 \mu \mathrm{L})$ containing GOX before $\mathrm{O}_{2}$ detection (at 24 and 48 hours). As shown in Figure 5C and 5D, bolus addition of glucose did not significantly affect the $\mathrm{O}_{2}$ content or the $\mathrm{H}_{2} \mathrm{O}_{2}$ concentration in solution.

To test whether replacing a new $\mathrm{GOX}_{\mathrm{PEGA}}$ gel would prolong hypoxia in the solution, we removed the old gel after 24 hours and placed a freshly prepared GOX formulation). We also added freshly prepared CAT solution. Figure S3 shows that the $\mathrm{O}_{2}$ content was maintained at $\sim 5 \%$ at 30 hours (i.e., 6 hours post gel replacement), whereas the $\mathrm{O}_{2}$ 
content was $\sim 9 \%$ in the control group (i.e., without replacing GOXPEGA gels). However, the $\mathrm{O}_{2}$ content in both conditions increased to above $14 \%$ at 48 hours.

\subsection{Cytocompatibility of enzyme-immobilized hydrogels}

Figure 6 shows the cytocompatibility of enzyme-free (i.e., PEGDA only) and GOXimmobilized hydrogels. Molm14 cell viability was maintained above 95\% over the course of 48 hours in the presence of an enzyme-free PEGDA hydrogel (Figure 6A). These cells were also

proliferating over time, as indicated by steady increase in cell density (Figure 6B). When a GOX viability in the initial 24 hours was comparable to that in the media-only control (around $90 \%$, Figure 6C). However, after 48 hours of in vitro culture, Molm14 cell viability declined sharply to $\sim 55 \%$. In addition to the decreased cell viability after 48 hours, a similar trend can be seen with cell density over time (Figure 6D). Specifically, there was no significant difference in cell density between the control and experimental group at 6 hours (i.e., $\sim 3.6 \times 10^{5}$ cells $/ \mathrm{mL}$ ). By 48 hours the Molm14 cell density in the media-only control group had increased to $\sim 5.5 \times 10^{5}$ cells $/ \mathrm{mL}$, whereas the Molm14 cell density in the GOX-immobilized hydrogel group decreased significantly to $\sim 2.2 \times 10^{5} \mathrm{cells} / \mathrm{mL}$.

\subsection{Enzyme-induced hypoxia in the presence of cells}

The main focus of this study was to develop an enabling material technology for facilitating a wide variety of in vitro cancer cell culture. We choose anchorage-independent acute myeloid leukemia (AML) cell line Molm14 and anchorage-dependent hepatocellular carcinoma (HCC) cell line Huh7 to test the utility of the hypoxia-inducing hydrogels. The survival and progression of these cells, just like many other cancer cell types, were significantly affected

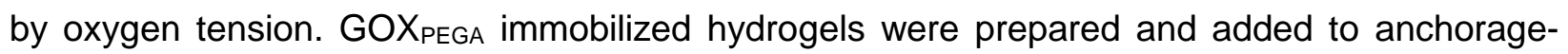
independent Molm14 cells cultured directly. As shown in Figure 7A, solution hypoxia was rapidly induced and maintained below $5 \% \mathrm{O}_{2}$ from 6 to 24 hours. By 48 hours, however, $\mathrm{O}_{2}$ 
concentration had risen to near normoxia $\left(17-20 \% \mathrm{O}_{2}\right)$, a result consistent with the cell-free measurements shown in Figure 5A and 5C. For anchorage-dependent cell Huh7, GOX PEGA- $^{-}$ immobilized hydrogel was placed in a standard transwell device and co-cultured with the cells adhered to the surface of a multi-well plate. The purpose of using a transwell device was to prevent direct contact of the gel with the cells, which could mechanically disrupt cell attachment.

Figure 7C shows that $\mathrm{O}_{2}$ profile development was similar to that for Molm14 cells. Low $\mathrm{O}_{2}$ concentration was reached quickly and maintained up to 24 hours. By 48 hours, the $\mathrm{O}_{2}$ content had returned to almost normoxia. As expected, the addition of $\mathrm{CoCl}_{2}$ in cell culture media did not change $\mathrm{O}_{2}$ tension (Figure $7 \mathrm{C}$ ).

\subsection{Effect of enzyme-induced hypoxia on hypoxic gene expression}

In addition to cell viability, the expression of hypoxia associated gene carbonic anhydrase 9 (CA9) in Molm14 cells was evaluated at 6 and 24 hours of culture in the presence of a GOX-immobilized hydrogel. As shown in Figure 7B, enzyme-induced hypoxia increased the expression of CA9 significantly compared with control groups ( $\sim 3$-fold and $\sim 10$-fold higher at 6 and 24 hours of culture, respectively). For Huh7 cells, the expression of carbonic anhydrase 9 (CA9) and lysyl oxidase (LOX) was examined after the cells were exposed to the enzymeimmobilized hydrogel (Note: no detectable LOX expression was found in Molm14 cells). In selected groups, $\mathrm{CoCl}_{2}$ was added as another control for chemically stimulated hypoxic response. As shown in Figure 7D, $\mathrm{CoCl}_{2}$ failed to upregulate CA9 expression in the first 24 hours. After the same period of time in culture, the use of GOXPEGA gels + CAT led to a 20-fold increase in CA9 expression in Huh7 cells. After 48 hours, the addition of $\mathrm{CoCl}_{2}$ caused $\sim 15$-fold upregulation in CA9 mRNA expression, which was much lower than that induced by the enzyme-immobilized hydrogel group ( 80 -fold higher). In Huh7 cells, LOX mRNA expression was upregulated only in cells co-cultured with a GOXPEGA gel ( 2.5 fold, Figure S4). The addition of $\mathrm{CoCl}_{2}$ did not increase the expression of LOX in Huh7 cells. 


\section{Discussion}

This work aims to develop an enabling material strategy to create solution hypoxia for in vitro cancer cell culture without using complex devices/instrument. GOX-immobilized hydrogel was used as a proof-of-concept to demonstrate the ability of enzyme-immobilized gel to induce sustained hypoxia. We established the concentration of GOX (4.5 $\mu \mathrm{g}$ in $1 \mathrm{~mL}$ buffer) required to induce hypoxia $(<5 \%)$ within 5 minutes (Figure 1B). As expected, the addition of CAT partially replenished $\mathrm{O}_{2}$, leading to slight decrease in reaction velocity (Figure 1C). Chemical modification is necessary for the immobilization of GOX into hydrogels but significant modification might result in the loss of enzymatic activity, especially when the degree of enzyme modification that we have achieved was more than $90 \%$ of the available amine groups on enzyme surface. Analyses of enzyme reaction kinetics revealed that chemical modification (i.e., PEG-acrylation) of GOX only caused slight reduction of its $\mathrm{O}_{2}$ consumption ability (Figure 2 \& Table 1). The kinetic parameters of GOX obtained from this study were relatively low compared to values reported in the literature. (Gibson et al., 1964). This could be attributed to the differences in experimental conditions and the methods for which enzyme activities were measured. Conventionally, the activity of GOX is assayed by monitoring $\beta$-D-glucose concentration, whereas in the current study we detected $\mathrm{O}_{2}$ concentration. Although the oxygen contributed from atmospheric air or from reduced $\mathrm{H}_{2} \mathrm{O}_{2}$ (by CAT or natural reduction with a halflife of $\sim 10$ minutes in cell culture environment, Mueller et al., 2009) would complicate the analysis results, the current detection method was necessary as the main purpose of this project was to investigate whether enzyme-immobilized hydrogels could induce solution hypoxia for in vitro cell culture under ambient conditions (i.e., with $\mathrm{O}_{2}$ diffusion from the air). The slight reduction of activity in modified enzyme was likely caused by changes in secondary and tertiary protein structure following significant GOX surface modification (Pandey et al., 2007). Nonetheless, both unmodified GOX and GOXPEGA were able to induce solution hypoxia $\left(\mathrm{O}_{2}<\right.$ $5 \%$ ) within a few minutes (Figure 2B) and solution hypoxia was sustained for up to 24 hours 
(Figures 3). Additionally, no statistically significant difference was observed between GOX and GOX $_{P E G A}$ activity within the first 24 hours (Figure 3). Our results were consistent to that reported by Kang et al. where methacryloyl-modified GOX exhibited similar enzymatic activity in solution compared with unmodified GOX (Kang and Bae, 2003). We also found that GOX polymerized in PEGDA hydrogels was able to induce hypoxia rapidly after dropping the gel in glucose-containing buffer solution. However, GOX-immobilized hydrogel could only sustain solution hypoxia for 24 hours. The restoration of $\mathrm{O}_{2}$ tension in the solution was not due to the lost of enzyme activity as $\mathrm{O}_{2}$ tension at the interior of the GOX-immobilized hydrogel was maintained below $2 \%$ for up to 5 days (Figure 4B). It was likely that constant oxygen diffusion from the liquid-air interface supersedes oxygen consuming enzymatic reaction in the hydrogel. This hypothesis was supported by the fact that replacing the old gel with a freshly prepared GOX-immobilized hydrogel only prolonged hypoxia for a few hours (Figure S3). Another possible reason was that some enzymes were deactivated by the accumulation of acid byproduct gluconic acid and $\mathrm{H}_{2} \mathrm{O}_{2}$. To test whether $\mathrm{H}_{2} \mathrm{O}_{2}$ deactivated the enzyme, CAT was introduced in the solution to consume $\mathrm{H}_{2} \mathrm{O}_{2}$ (Figure 5). The increase of $\mathrm{O}_{2}$ content in the solution (Figure 5A) coincided with the accumulation of $\mathrm{H}_{2} \mathrm{O}_{2}$ levels (Figure 5B), supporting the likelihood of enzyme deactivation by elevated $\mathrm{H}_{2} \mathrm{O}_{2}$ concentration. This phenomenon has been reported in membrane-bound GOX and CAT system where both enzyme activities were reduced with increased $\mathrm{H}_{2} \mathrm{O}_{2}$ concentrations over time (Blandino et al., 2002; Tse and Gough, 1987). It was not likely that the enzymatic reactions depleted most of the substrate (i.e., $\beta$-Dglucose) after 24 hours, as the addition of extra $\beta$-D-glucose periodically before $\mathrm{O}_{2}$ tension measurement did not cause further $\mathrm{O}_{2}$ consumption. Whether there was additional glucose addition or not, no statistically significant difference was found in $\mathrm{O}_{2}$ (Figure $5 \mathbf{C}$ ) or $\mathrm{H}_{2} \mathrm{O}_{2}$ concentration (Figure 5D).

To demonstrate the utility of this immobilized enzyme system on in vitro cell culture, we characterized cell viability, proliferation, and the expression of hypoxia-regulated genes (i.e., 
CA9 or LOX) in cells cultured in the presence of GOX-immobilized hydrogels. Both CA9 and LOX are downstream targets of HIF1 $\alpha$ and are well-established genes associated with cancer metastasis and metabolism in hypoxic environments (Erler et al., 2006; Wykoff et al., 2000). Detecting the expression of these two genes allowed us to evaluate the utility of our hypoxiainducing hydrogels. Results show that the expression of CA9 and LOX was significantly higher in Huh7 cells cultured with GOX-immobilized hydrogels (Figures 7D \& S4). Molm14 cells also had increased CA9 expression (Figure 7B). However, no expression of LOX was detected (control group included); there is also a lack of literature for LOX expression with Molm14 cells or the sister Molm13 cell line. Nonetheless, similar data for both CA9 and LOX expression was reported by Askoxylakis et al. where GOX and CAT were dissolved in culture media to generate hypoxia for culturing head and neck squamous carcinoma cells (Askoxylakis et al., 2011). Although GOX-immobilized hydrogel was effective in inducing solution hypoxia under ambient conditions, these gels appeared to hinder cell viability and proliferation after the cells were exposed to the hydrogel system for longer than 24 hours. This was most likely attributed to the accumulation of cytotoxic byproduct, namely gluconic acid and $\mathrm{H}_{2} \mathrm{O}_{2}$. This is not a unique problem to our system as other GOX/CAT-induced hypoxia culture systems (e.g., soluble or membrane-bound enzyme) also exhibited decreased cytocompatibility after 24 hours of culture (Askoxylakis et al., 2011; Huang et al., 2013; Zitta et al., 2012). One potential solution for this drawback is to replace the GOX-immobilized hydrogel and the CAT supplemented media frequently. Providing fresh media and hydrogel allows hypoxia to quickly be reestablished and maintained for periods lasting for at least 24 hours. Furthermore, media acidification by gluconic acid could be reduced by supplementing cell culture media with HEPES, which provides strong buffering effect without altering normal cell physiology.

Lastly, other $\mathrm{O}_{2}$-consuming enzymes (e.g., laccase, bilirubin oxidase, polyphenol oxidase, catechol oxidase, etc.) could be immobilized in hydrogels for inducing solution hypoxia. One benefit of these enzymes is that they do not produce $\mathrm{H}_{2} \mathrm{O}_{2}$, which would provide for longer 
hypoxia without enzymatic inactivation or adverse effects of reactive oxygen species on cells. Additionally, different reaction speeds corresponding to specific enzymes can be used to create fast or slow hypoxia induction.

\section{Conclusion}

In summary, we have developed enzyme-immobilized hydrogels to rapidly induce hypoxia for in vitro cell culture. Even when the solution was kept under ambient air, the GOXimmobilized hydrogel was able to establish and sustain in vitro hypoxic conditions $\left(<5 \% \mathrm{O}_{2}\right)$ for 6 to 24 hours, a time frame sufficient for many biological characterizations and assays. Although PEGDA hydrogel retains and stabilizes GOX in the gel for at least five days, a continuous supply of $\mathrm{O}_{2}$ from the air eventually overcomes the enzymatic $\mathrm{O}_{2}$ reduction. Furthermore, the accumulation of reaction by-products and glucose depletion might limit the utility of the current system to applications within 24 hours. Regardless, enzyme-immobilized hydrogels provide a simple, flexible, and more efficient option to induce realistic hypoxia compared with the use of chemical compounds. Future work will focus on prolonging the timespan of hypoxia through system optimization or via the use of other oxygen consuming enzymes.

\section{Acknowledgments}

This work was supported by the National Science Foundation (CAREER Award, DMR \#1452390, to CL), Leukemia \& Lymphoma Society (New Idea Award, to HK), and the Department of Biomedical Engineering at IUPUI (Graduate Research Fellowship, to CSD). The authors thank Dr. Tsai-Yu Lin for his assistance in real-time PCR. 


\section{References}

Allen, C.B., Schneider, B.K., White, C.W., (2001) Limitations to oxygen diffusion and equilibration in in vitro cell exposure systems in hyperoxia and hypoxia. American journal of physiology. Lung cellular and molecular physiology 281, L1021-1027.

An, W.G., Kanekal, M., Simon, M.C., Maltepe, E., Blagosklonny, M.V., Neckers, L.M., (1998) Stabilization of wild-type p53 by hypoxia-inducible factor 1alpha. Nature 392, 405-408.

Askoxylakis, V., Millonig, G., Wirkner, U., Schwager, C., Rana, S., Altmann, A., Haberkorn, U., Debus, J., Mueller, S., Huber, P.E., (2011) Investigation of tumor hypoxia using a twoenzyme system for in vitro generation of oxygen deficiency. Radiation oncology 6, 35 .

Baumann, R.P., Penketh, P.G., Seow, H.A., Shyam, K., Sartorelli, A.C., (2008) Generation of oxygen deficiency in cell culture using a two-enzyme system to evaluate agents targeting hypoxic tumor cells. Radiation research 170, 651-660.

Blandino, A., Macías, M., Cantero, D., (2002) Modelling and simulation of a bienzymatic reaction system co-immobilised within hydrogel-membrane liquid-core capsules. Enzyme and microbial technology 31, 556-565.

Blatchley, M., Park, K.M., Gerecht, S., (2015) Designer Hydrogels for Precision Control of Oxygen Tension and Mechanical Properties. Journal of materials chemistry. B, Materials for biology and medicine 3, 7939-7949.

Broxmeyer, H.E., O'Leary, H.A., Huang, X., Mantel, C., (2015) The importance of hypoxia and extra physiologic oxygen shock/stress for collection and processing of stem and progenitor cells to understand true physiology/pathology of these cells ex vivo. Current opinion in hematology $22,273-278$.

Choi, D., Lee, W., Park, J., Koh, W., (2008) Preparation of poly(ethylene glycol) hydrogels with different network structures for the application of enzyme immobilization. Bio-medical materials and engineering 18, 345-356. 
De Miguel, M.P., Alcaina, Y., de la Maza, D.S., Lopez-Iglesias, P., (2015) Cell metabolism under microenvironmental low oxygen tension levels in stemness, proliferation and pluripotency. Current molecular medicine 15, 343-359.

Erler, J.T., Bennewith, K.L., Nicolau, M., Dornhofer, N., Kong, C., Le, Q.-T., Chi, J.-T.A., Jeffrey, S.S., Giaccia, A.J., (2006) Lysyl oxidase is essential for hypoxia-induced metastasis. Nature 440, 1222-1226.

Fairbanks, B.D., Schwartz, M.P., Bowman, C.N., Anseth, K.S., (2009) Photoinitiated polymerization of PEG-diacrylate with lithium phenyl-2,4,6-trimethylbenzoylphosphinate: polymerization rate and cytocompatibility. Biomaterials 30, 6702-6707.

Fruehauf, J.P., Meyskens, F.L., Jr., (2007) Reactive oxygen species: a breath of life or death? Clinical cancer research : an official journal of the American Association for Cancer Research 13, 789-794.

Giaccia, A., Siim, B.G., Johnson, R.S., (2003) HIF-1 as a target for drug development. Nature reviews. Drug discovery 2, 803-811.

Gibson, Q.H., Swoboda, B.E., Massey, V., (1964) Kinetics and Mechanism of Action of Glucose Oxidase. The Journal of biological chemistry 239, 3927-3934.

Han, Y.H., Xia, L., Song, L.P., Zheng, Y., Chen, W.L., Zhang, L., Huang, Y., Chen, G.Q., Wang, L.S., (2006) Comparative proteomic analysis of hypoxia-treated and untreated human leukemic U937 cells. Proteomics 6, 3262-3274.

Hao, Y., Lin, C.C., (2014) Degradable thiol-acrylate hydrogels as tunable matrices for threedimensional hepatic culture. Journal of biomedical materials research. Part A 102, 38133827.

Hielscher, A., Gerecht, S., (2015) Hypoxia and free radicals: role in tumor progression and the use of engineering-based platforms to address these relationships. Free radical biology \& medicine $79,281-291$. 
Hockel, M., Vaupel, P., (2001) Tumor hypoxia: definitions and current clinical, biologic, and molecular aspects. Journal of the National Cancer Institute 93, 266-276.

Huang, Y., Zitta, K., Bein, B., Steinfath, M., Albrecht, M., (2013) An insert-based enzymatic cell culture system to rapidly and reversibly induce hypoxia: investigations of hypoxiainduced cell damage, protein expression and phosphorylation in neuronal IMR-32 cells. Disease models \& mechanisms 6, 1507-1514.

Kang, S.I., Bae, Y.H., (2003) A sulfonamide based glucose-responsive hydrogel with covalently immobilized glucose oxidase and catalase. Journal of Controlled Release 86, 115-121.

Kirkman, H.N., Gaetani, G.F., (2007) Mammalian catalase: a venerable enzyme with new mysteries. Trends in biochemical sciences 32, 44-50.

Lewis, D.M., Park, K.M., Tang, V., Xu, Y., Pak, K., Eisinger-Mathason, T.S., Simon, M.C., Gerecht, S., (2016) Intratumoral oxygen gradients mediate sarcoma cell invasion. Proceedings of the National Academy of Sciences of the United States of America 113, 9292-9297.

Li, C., Chaung, W., Mozayan, C., Chabra, R., Wang, P., Narayan, R.K., (2016) A New Approach for On-Demand Generation of Various Oxygen Tensions for In Vitro Hypoxia Models. PloS one 11, e0155921.

Liu, L., Simon, M.C., (2004) Regulation of transcription and translation by hypoxia. Cancer biology \& therapy 3, 492-497.

Millonig, G., Hegedusch, S., Becker, L., Seitz, H.K., Schuppan, D., Mueller, S., (2009) Hypoxiainducible factor 1 alpha under rapid enzymatic hypoxia: cells sense decrements of oxygen but not hypoxia per se. Free radical biology \& medicine 46, 182-191.

Mueller, S., Millonig, G., Waite, G.N., (2009) The GOX/CAT system: a novel enzymatic method to independently control hydrogen peroxide and hypoxia in cell culture. Advances in medical sciences $54,121-135$. 
Pal, P., Datta, S., Bhattacharya, P., (2000) Studies on the modeling and simulation of a sequential bienzymatic reaction system immobilized in emulsion liquid membrane. Biochemical engineering journal 5, 89-100.

Pandey, P., Singh, S.P., Arya, S.K., Gupta, V., Datta, M., Singh, S., Malhotra, B.D., (2007) Application of thiolated gold nanoparticles for the enhancement of glucose oxidase activity. Langmuir : the ACS journal of surfaces and colloids 23, 3333-3337.

Park, K.M., Blatchley, M.R., Gerecht, S., (2014) The design of dextran-based hypoxia-inducible hydrogels via in situ oxygen-consuming reaction. Macromolecular rapid communications 35, 1968-1975.

Park, K.M., Gerecht, S., (2014) Hypoxia-inducible hydrogels. Nature communications 5, 4075.

Peng, C.C., Liao, W.H., Chen, Y.H., Wu, C.Y., Tung, Y.C., (2013) A microfluidic cell culture array with various oxygen tensions. Lab on a chip 13, 3239-3245.

Rajan, N., Narayan, A., Wu, Z., Wu, P., Ahn, C.H., Narayan, R.K., Li, C., (2013) A novel oxygen tension programmable microfluidic system (oPROMs) for in vitro cell biology studies. 2013 Transducers \& Eurosensors XXVII: The 17th International Conference on SolidState Sensors, Actuators and Microsystems (TRANSDUCERS \& EUROSENSORS XXVII), pp. 412-415.

Semenza, G.L., (2000) HIF-1: mediator of physiological and pathophysiological responses to hypoxia. Journal of applied physiology 88, 1474-1480.

Simon, M.C., Keith, B., (2008) The role of oxygen availability in embryonic development and stem cell function. Nature reviews. Molecular cell biology 9, 285-296.

Sobotta, M.C., Barata, A.G., Schmidt, U., Mueller, S., Millonig, G., Dick, T.P., (2013) Exposing cells to H2O2: a quantitative comparison between continuous low-dose and one-time high-dose treatments. Free radical biology \& medicine 60, 325-335. 
Trachootham, D., Alexandre, J., Huang, P., (2009) Targeting cancer cells by ROS-mediated mechanisms: a radical therapeutic approach? Nature reviews. Drug discovery 8, 579591.

Tse, P.H., Gough, D.A., (1987) Time-dependent inactivation of immobilized glucose oxidase and catalase. Biotechnology and bioengineering 29, 705-713.

Wu, Q., Wang, L., Yu, H., Wang, J., Chen, Z., (2011) Organization of glucose-responsive systems and their properties. Chemical reviews 111, 7855-7875.

Wykoff, C.C., Beasley, N.J.P., Watson, P.H., Turner, K.J., Pastorek, J., Sibtain, A., Wilson, G.D., Turley, H., Talks, K.L., Maxwell, P.H., Pugh, C.W., Ratcliffe, P.J., Harris, A.L., (2000) Hypoxia-inducible Expression of Tumor-associated Carbonic Anhydrases. Cancer Research 60, 7075-7083.

Zitta, K., Meybohm, P., Bein, B., Huang, Y., Heinrich, C., Scholz, J., Steinfath, M., Albrecht, M., (2012) Salicylic acid induces apoptosis in colon carcinoma cells grown in-vitro: influence of oxygen and salicylic acid concentration. Experimental cell research 318, 828-834. 


\section{Figure Captions}

Figure 1. Enzyme reaction mechanisms and soluble GOX induced solution hypoxia. (A) Reaction equilibrium of GOX (i), CAT (ii), and combined reaction (iii). (B, C) GOX-induced $\mathrm{O}_{2}$ consumption in the absence (B) or presence of $9.8 \mu \mathrm{g} / \mathrm{mL}$ CAT (C). All reactions were carried out in $\mathrm{pH} 7.4$ PBS with constant stirring, at room temperature, and with $25 \mathrm{mM} \beta$-D-Glucose. (Mean \pm SEM, $n \geq 3$ ).

Figure 2. Effect of GOX modification on oxygen consumption. (A) Reaction scheme of GOX modification using Acryl-PEG-SVA. Protein structure for GOX was obtained from the RCSB Protein Data Bank (PDB-ID, 3QVP). (B) $\mathrm{O}_{2}$ consumption profile using soluble GOX or GOX $9.8 \mu \mathrm{g} / \mathrm{mL}$ CAT, and 25mM $\beta$-D-Glucose. (C) Reaction velocity of $\mathrm{O}_{2}$ consumption by GOX or $\mathrm{GOX}_{\mathrm{PEGA}}$ as a function of substrate $\beta$-D-glucose concentration. Values were generated from using $0.260 \mu \mathrm{M}$ GOX or GOX $\mathrm{PEGA}_{\text {with }} 0.30$ to $25 \mathrm{mM}$ of $\beta$-D-glucose. All reactions were carried out in $\mathrm{pH}$ 7.4 PBS with constant stirring at $25^{\circ} \mathrm{C}$. (Mean $\pm \mathrm{SEM}, \mathrm{n} \geq 3$ ).

Figure 3. Effect of GOX modification on oxygen consumption over extended time. (A, B) $\mathrm{O}_{2}$ consumption profiles of unmodified and acrylated GOX in the absence (B) or presence of soluble CAT $(450 \mu \mathrm{g} / \mathrm{mL})$. All reactions were carried out in $\mathrm{pH} 7.4 \mathrm{PBS}$, at $25^{\circ} \mathrm{C}$, with $25 \mathrm{mM} \beta$ D-Glucose. $\left({ }^{* *} p<0.01 .{ }^{* * *} p<0.001\right.$. Mean \pm SEM, $\left.n \geq 3\right)$.

Figure 4. Effect of hydrogel-immobilized GOX $\mathrm{XEGA}_{\mathrm{P}}$ on oxygen consumption. (A) Schematic of $\mathrm{O}_{2}$ measurement within and outside of a PEGDA hydrogel. The sensor probe was fully extended from the needle for measuring $\mathrm{O}_{2}$ tension exterior to the hydrogel (left). To measure $\mathrm{O}_{2}$ content at the interior of the hydrogel (right), the optic fiber was recessed within its needle housing to prevent damage of the gel matrix to the probe. After penetration the fiber was extended to the tip of the needle cannula so that it was exposed to the interior of the hydrogel. 
(B) $\mathrm{O}_{2}$ consumption at the interior or exterior of GOX-immobilized hydrogels (120 $\mu \mathrm{L}$ of 8 wt\% PEGDA gel with $4 \mathrm{mg} / \mathrm{mL}$ GOX $P E G A) .\left({ }^{* * *} \mathrm{p}<0.001\right.$. Mean $\left.\pm \mathrm{SEM}, \mathrm{n} \geq 3\right)$.

Figure 5. Effect of supplements on oxygen consumption and $\mathrm{H}_{2} \mathrm{O}_{2}$ production by GOX gels. (A, B) Effect of soluble CAT addition on $\mathrm{O}_{2}$ tension (A) and $\mathrm{H}_{2} \mathrm{O}_{2}$ accumulation (B). (C, D) Effect of additional glucose on $\mathrm{O}_{2}$ tension (C) and $\mathrm{H}_{2} \mathrm{O}_{2}$ accumulation (D) in the presence of soluble CAT. Additional bolus injections of glucose $(50 \mu \mathrm{L}$ of $500 \mathrm{mM})$ was delivered 5 minutes before measuring $\mathrm{O}_{2}$ at 24 and 48 hour time points. Hydrogels $(60 \mu \mathrm{L})$ were formed by 15 wt\% PEGDA co-polymerized with $6 \mathrm{mg} / \mathrm{mL}$ GOX $\mathrm{PEGA}$. All reactions were carried out in $\mathrm{pH} 7.4 \mathrm{PBS}$ at $37^{\circ} \mathrm{C} .\left({ }^{* *} p<0.01 .{ }^{* *} p<0.001\right.$. Mean \pm SEM, $\left.n \geq 3\right)$.

Figure 6. Cytocompatibility of PEGDA hydrogels with or without immobilized GOX Molm14 cell viability $(A, C)$ and density $(B, D)$ when cultured in the absence (i.e., Empty Gel; $A$ \& B) or presence (C, D) of immobilized GOX ${ }_{\mathrm{PEGA}}$ Gel + CAT (6 mg/mL). Hydrogels were formed by 15 wt\% PEGDA. CAT in media: $0.54 \mathrm{mg} / \mathrm{mL}\left({ }^{*} \mathrm{p}<0.05 .{ }^{* *} \mathrm{p}<0.001\right.$. Mean \pm SEM, $\left.\mathrm{n} \geq 3\right)$.

Figure 7. Effect of enzyme-induced hypoxia on cell fate in vitro. $\mathrm{O}_{2}$ profile $(A, C)$ and $C A 9$ mRNA expression (B, D) in Molm14 (A, B) or Huh7 cells (C, D) cultured in the presence of a GOX $_{\text {PEGA }}(6 \mathrm{mg} / \mathrm{mL})$ immobilized 15 wt\% PEGDA hydrogel. CAT in media: $0.54 \mathrm{mg} / \mathrm{mL}$. $\mathrm{CoCl}_{2}$ $(150 \mu \mathrm{M})$ was added separately as an additional control group $\left({ }^{*} \mathrm{p}<0.05,{ }^{* *} \mathrm{p}<0.01,{ }^{* *} \mathrm{p}<\right.$ 0.001. Mean \pm SEM, $n \geq 3$ ). 
Figure 1.

$$
\begin{gathered}
\beta \text {-D-Glucose }+\mathrm{H}_{2} \mathrm{O}+\mathrm{O}_{2} \stackrel{\mathrm{GOX}}{\longrightarrow} \text { Gluconic Acid }+\mathrm{H}_{2} \mathrm{O}_{2} \\
\mathrm{H}_{2} \mathrm{O}_{2} \stackrel{\text { CAT }}{\longrightarrow} \mathrm{H}_{2} \mathrm{O}+1 / \mathrm{O}_{2} \\
\beta \text {-D-Glucose }+1 / 2 \mathrm{O}_{2} \stackrel{\mathrm{GOX}+\mathrm{CAT}}{\longrightarrow} \text { Gluconic Acid }
\end{gathered}
$$

A.

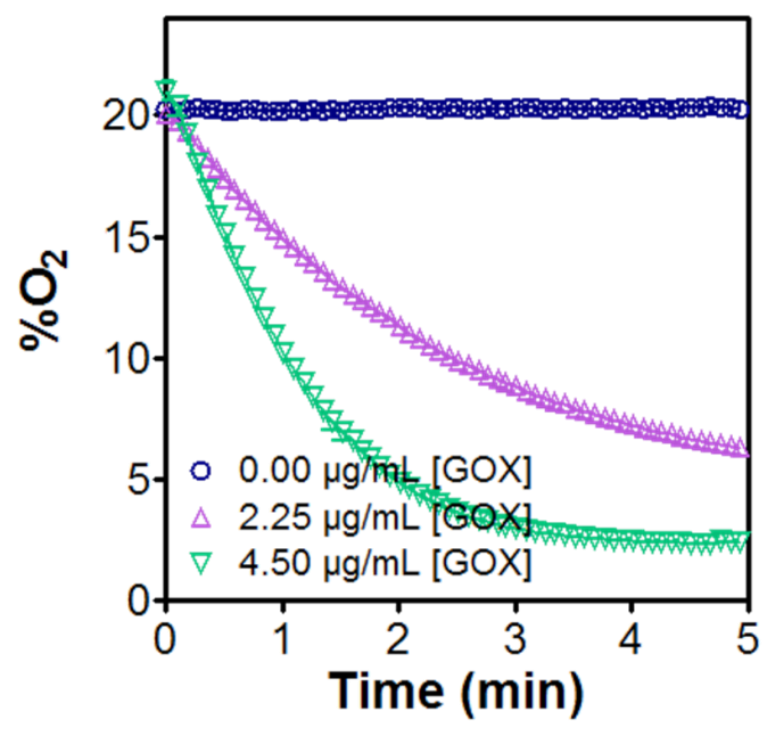

B.

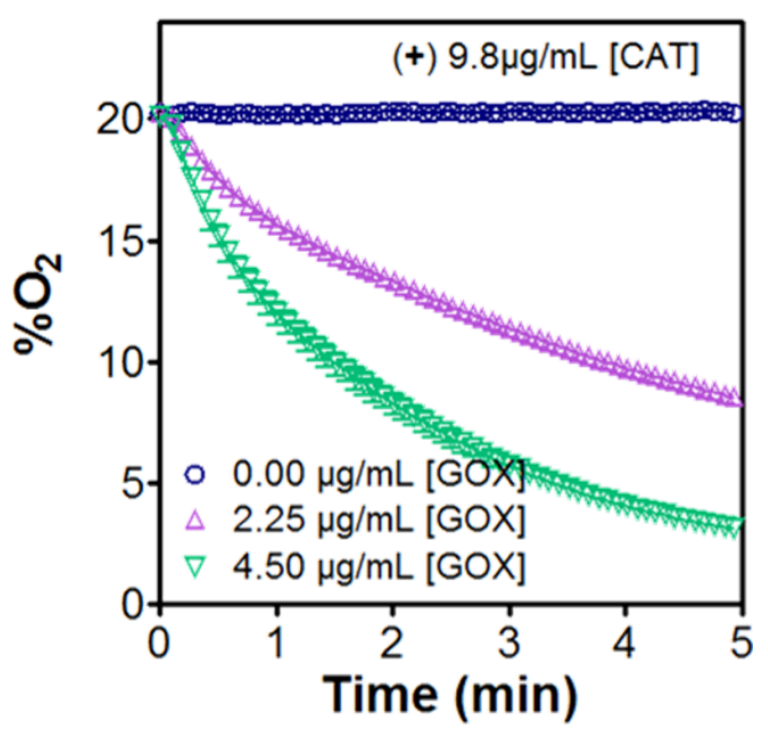


Figure 2.
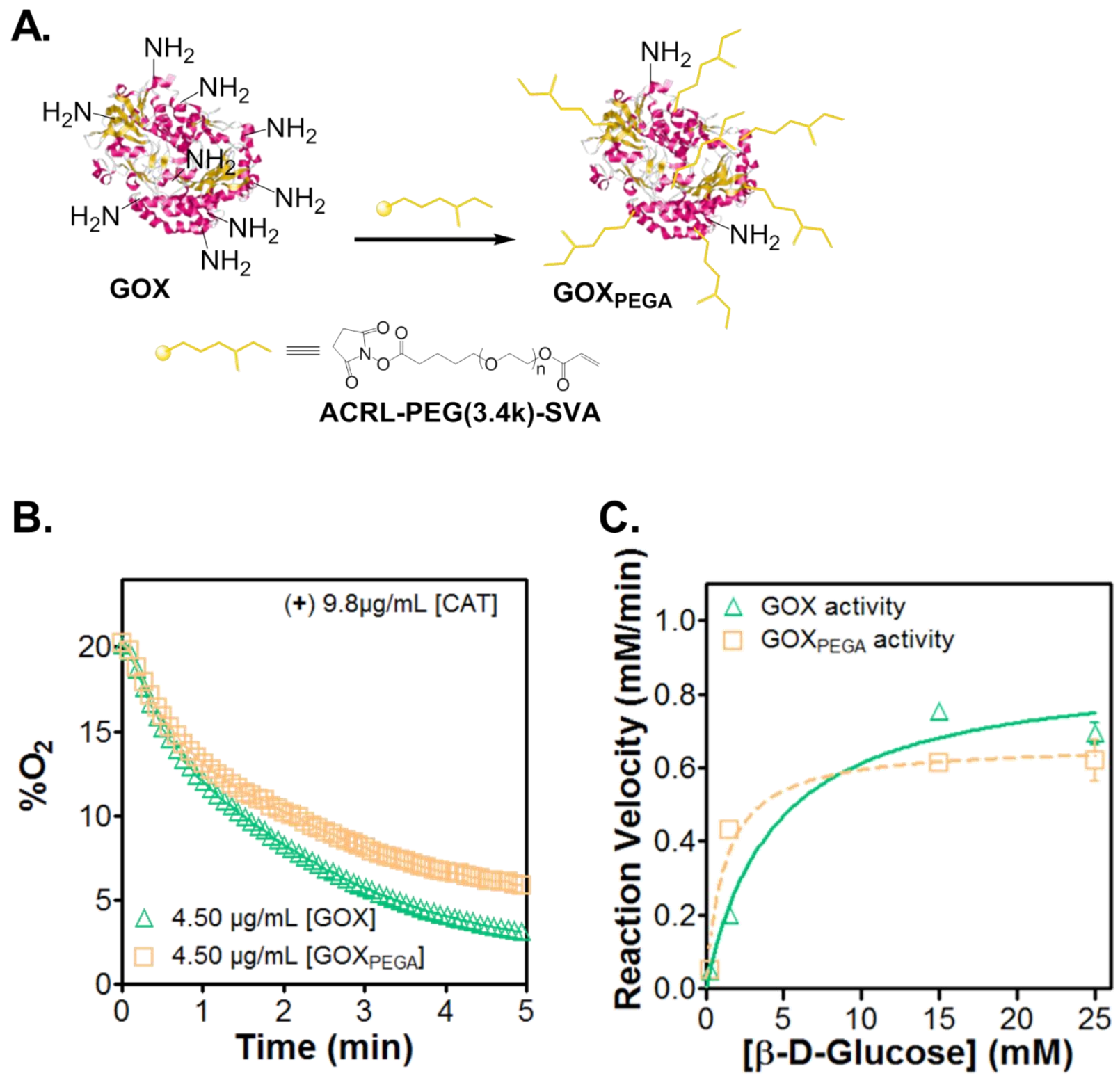
Figure 3.

A.
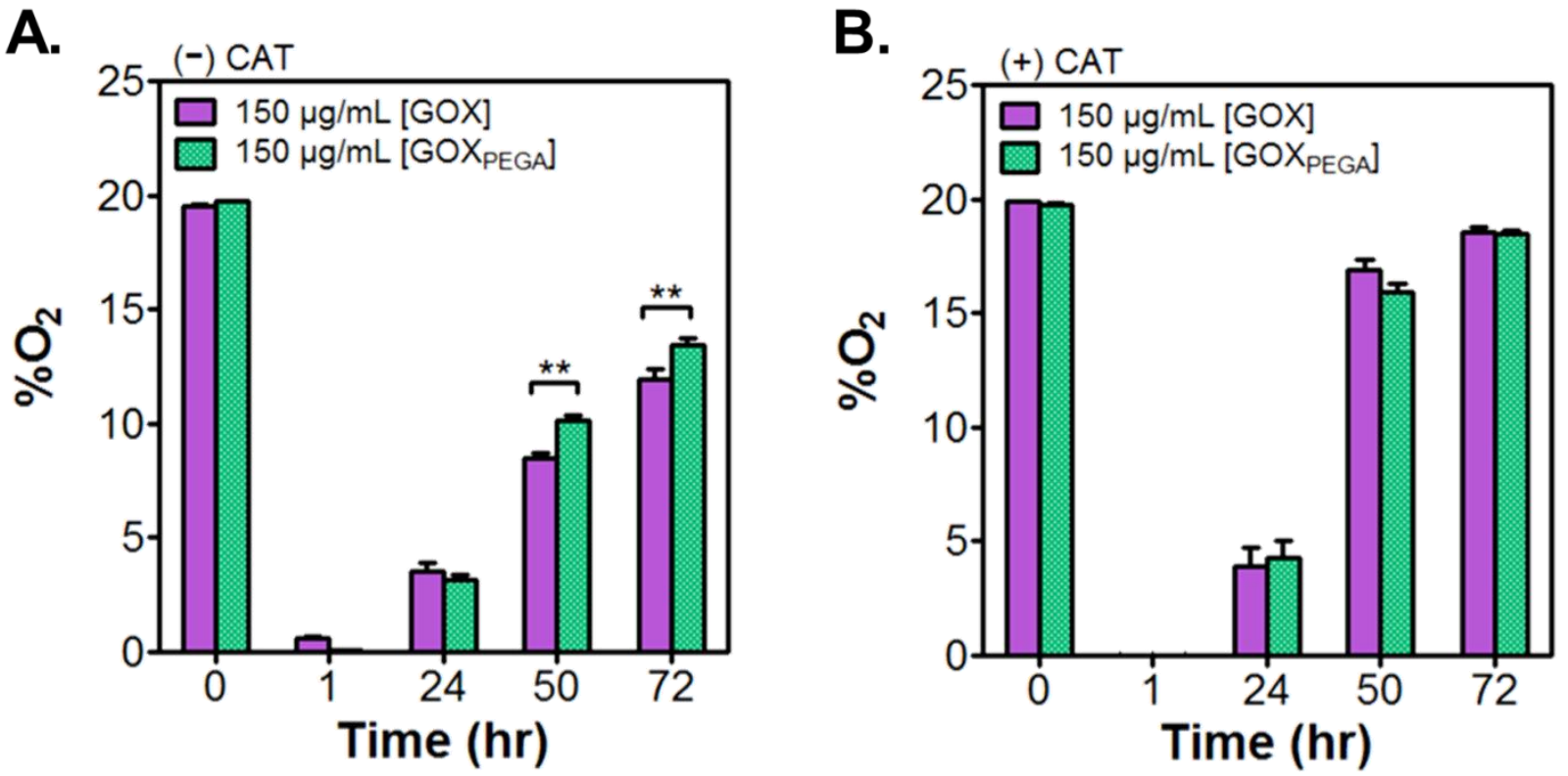
Figure 4.

A.
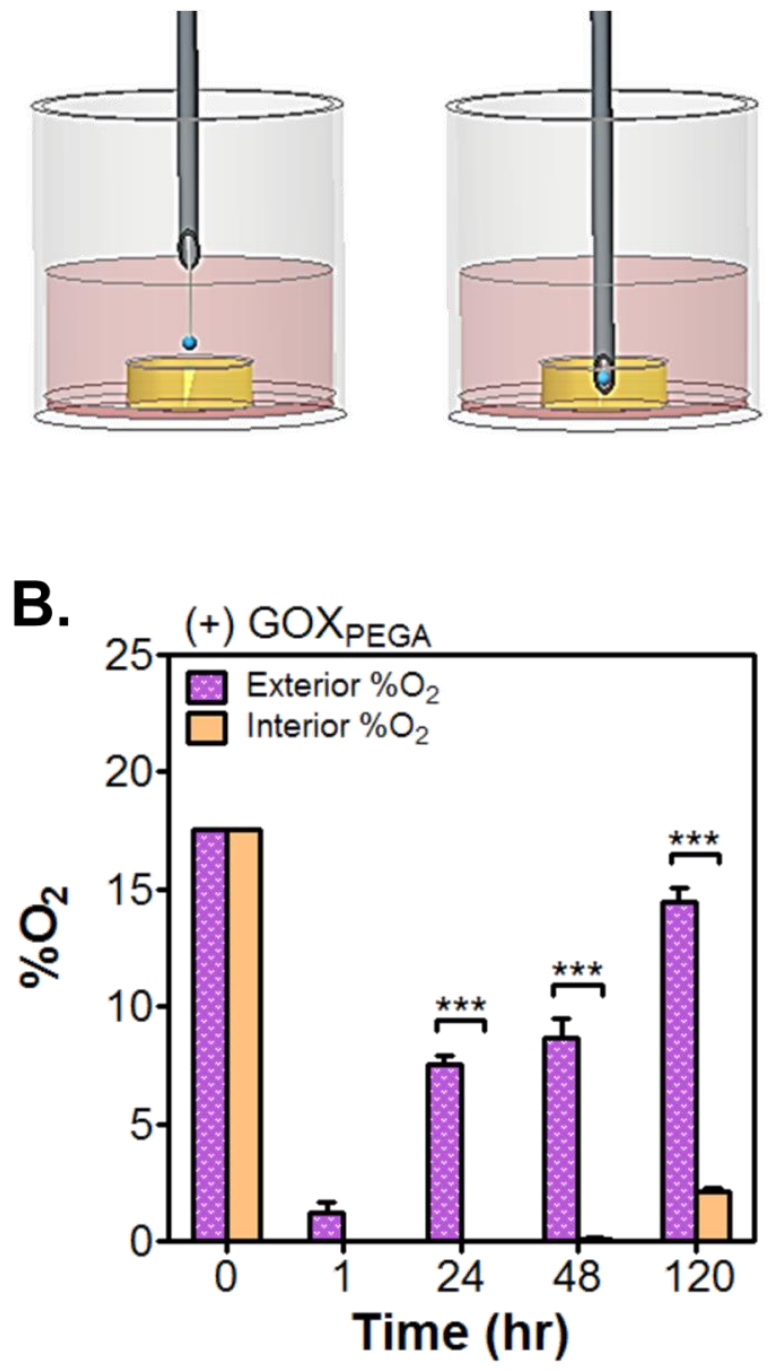
Figure 5.

A.

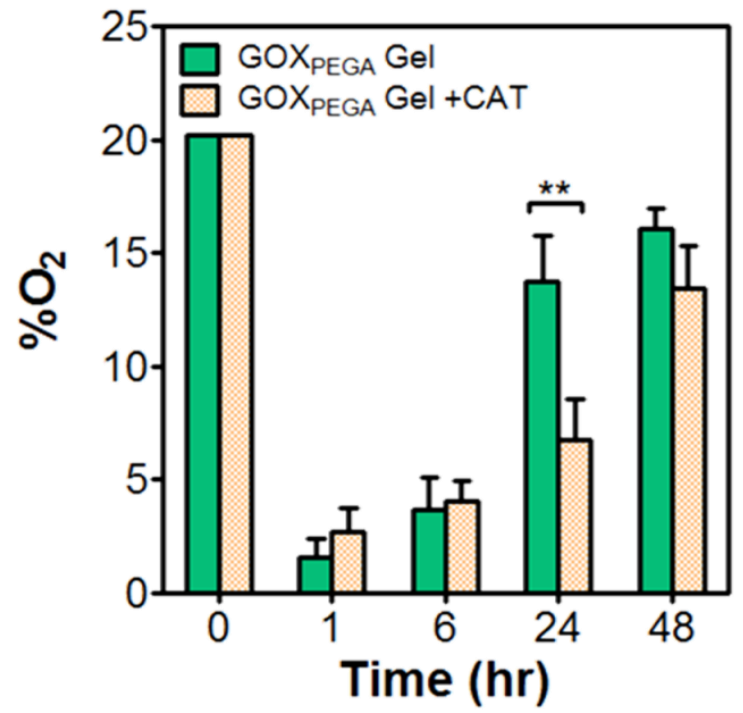

c.

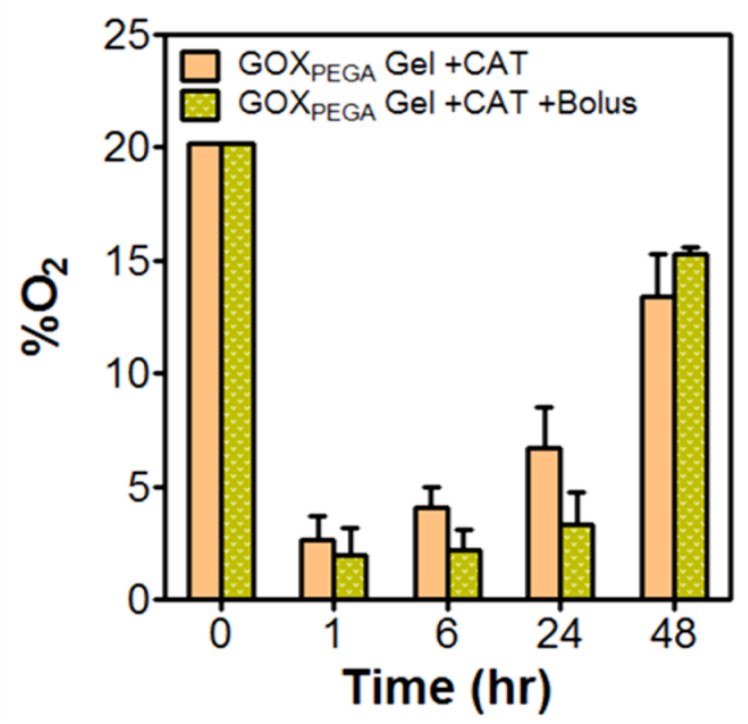

B.

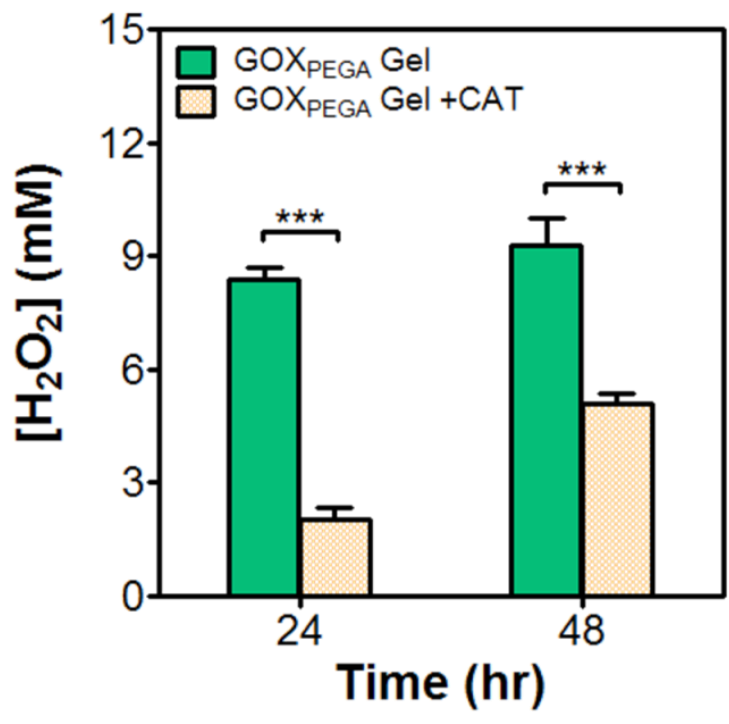

D.

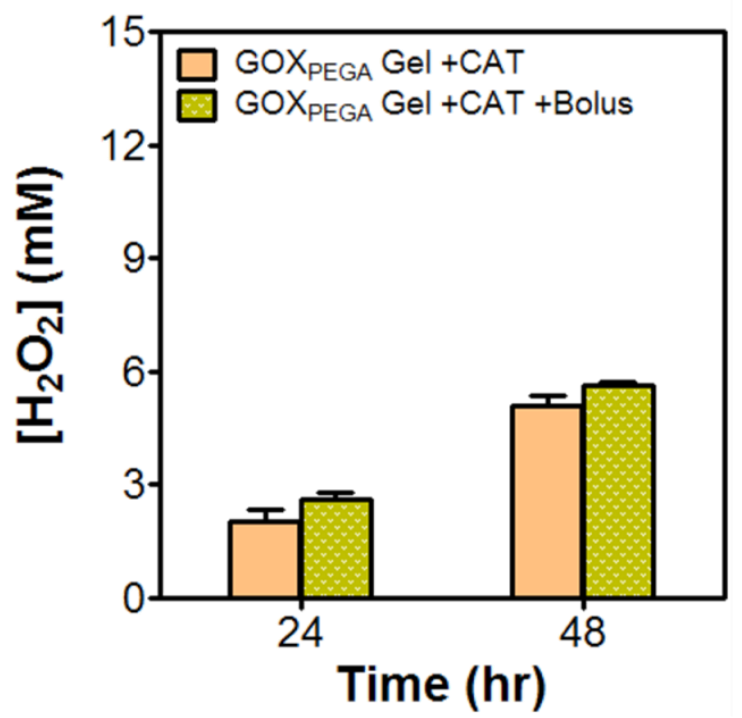


Figure 6

A.

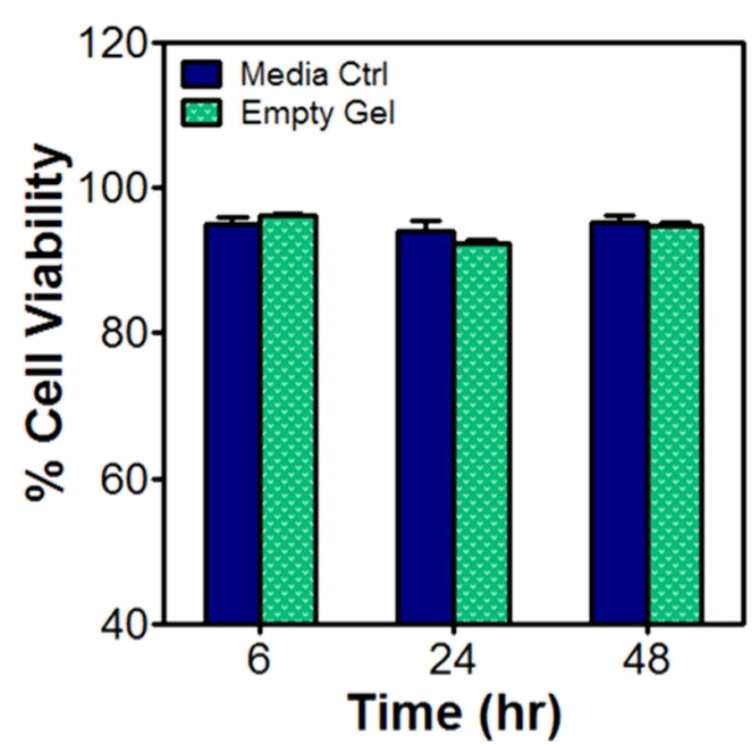

c.

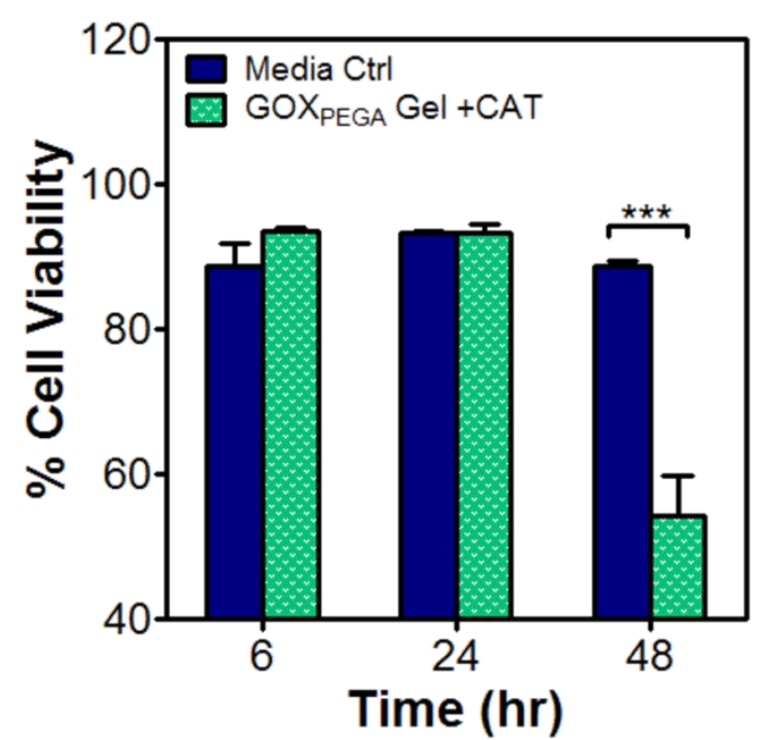

B.

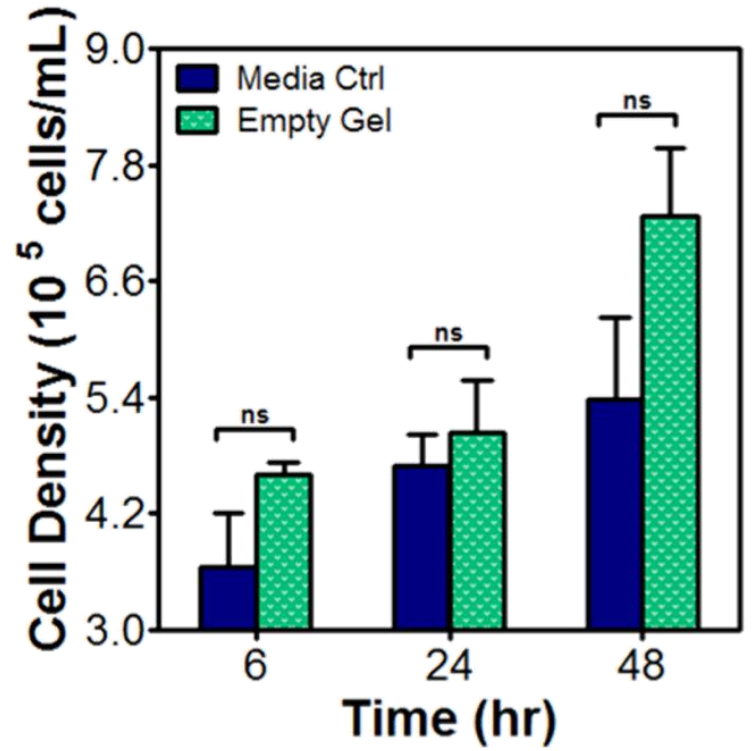

D.

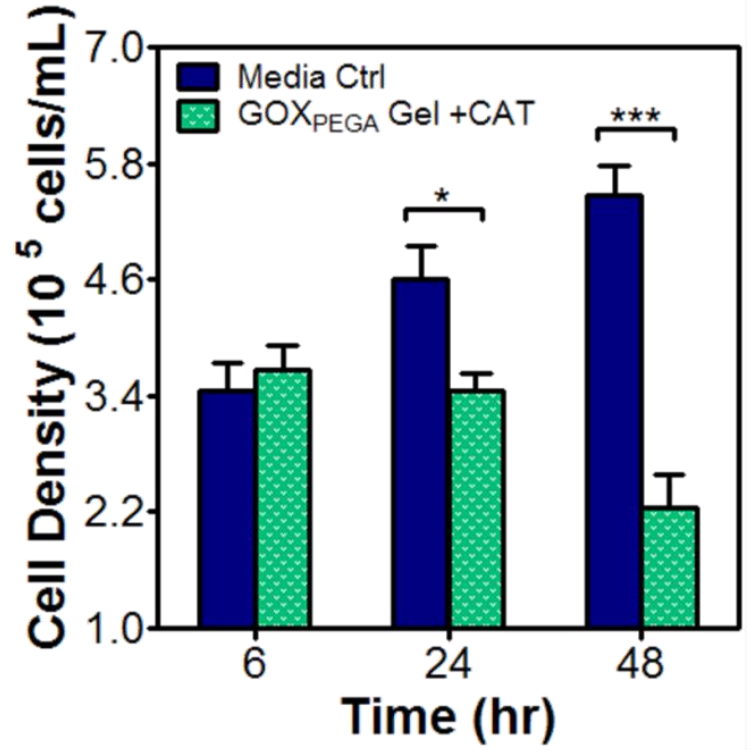


Figure 7.

A.

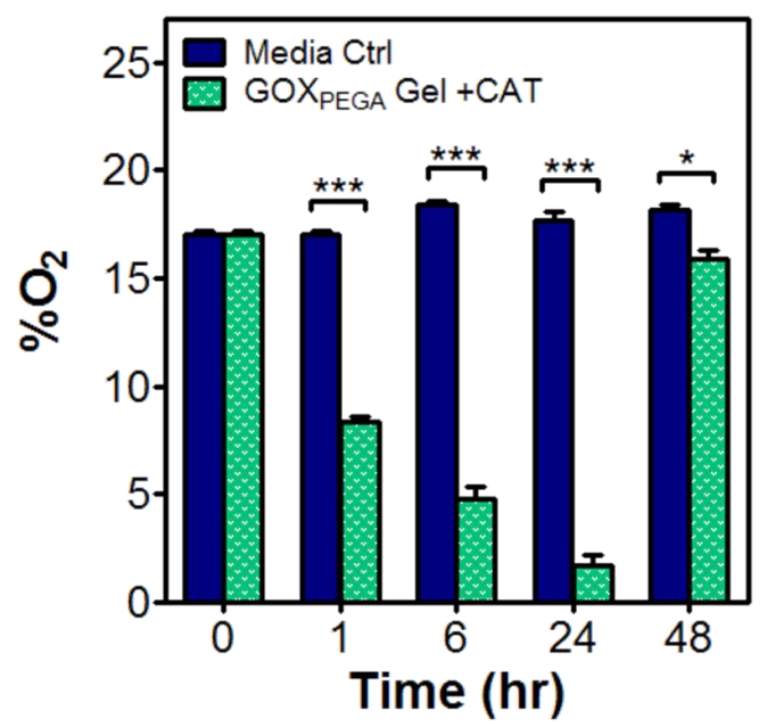

C.

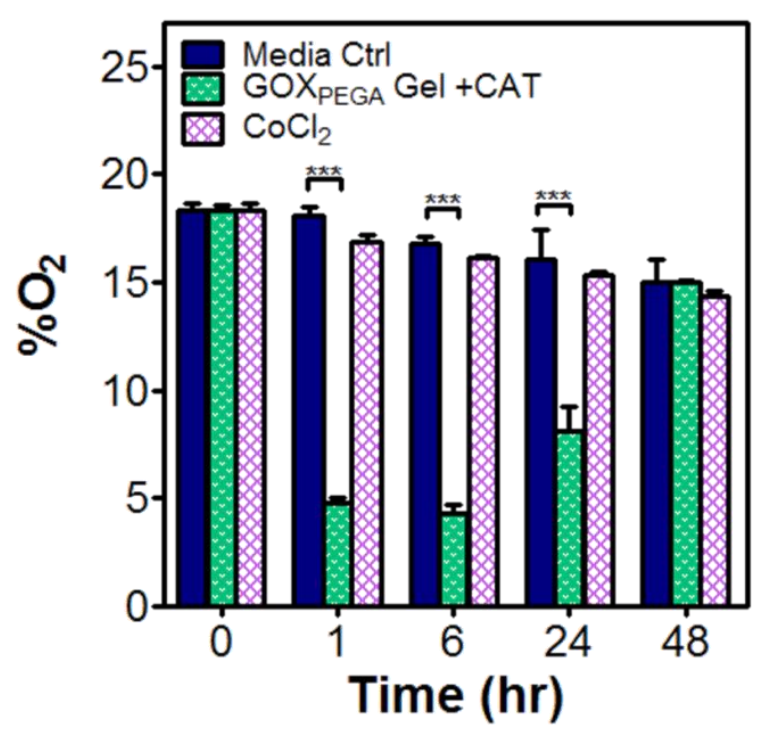

B.

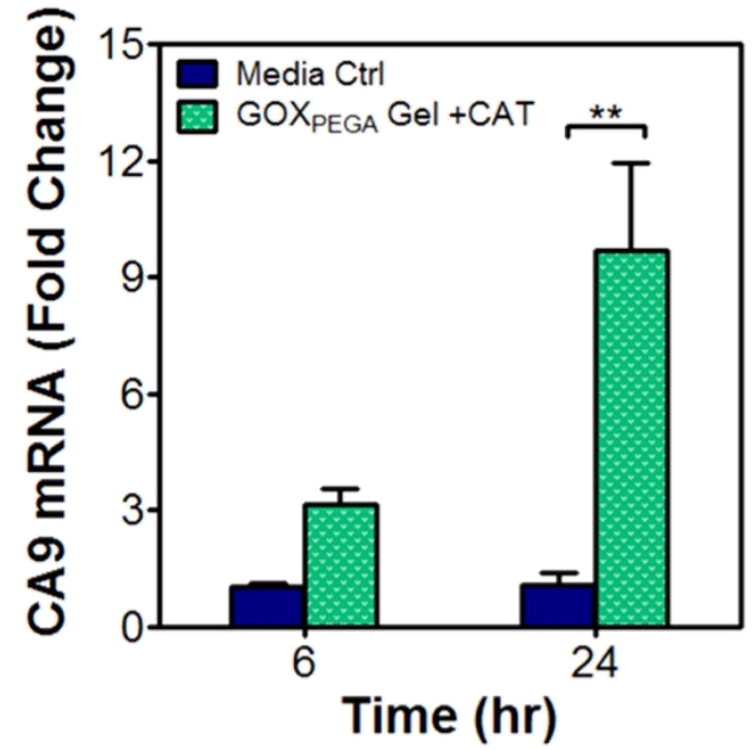

D.

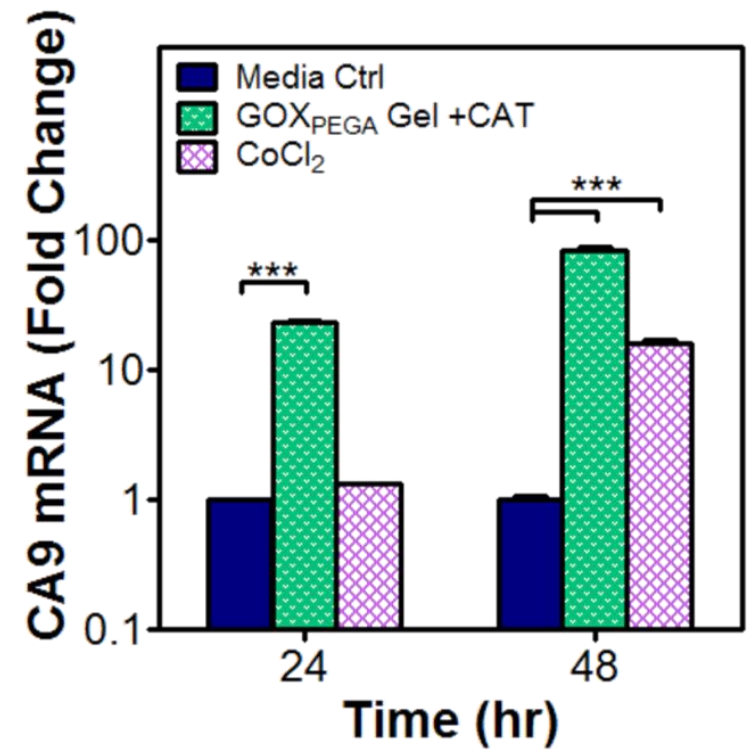


Table

Table 1. Michaelis-Menten constants of GOX and GOX $X_{P E G A}$.

\begin{tabular}{lll}
\hline & $V_{\max }\left(\mathrm{mM} \cdot \mathrm{min}^{-1}\right)$ & $\mathrm{K}_{\mathrm{m}}(\mathrm{mM})$ \\
\hline GOX & $0.88 \pm 0.05$ & $4.38 \pm 0.90$ \\
GOX $_{P E G A}$ & $0.66 \pm 0.03$ & $1.17 \pm 0.28$ \\
\hline
\end{tabular}

